\title{
Emotional and functional impact of DNA testing on patients with symptoms of Huntington's disease
}

\author{
J Jankovic, J Beach, T Ashizawa
}

\begin{abstract}
The potential impact of DNA testing on asymptomatic subjects at risk for Huntington's disease (HD) has been addressed by numerous studies, but the effect of revealing the genetic results to patients with a clinically established diagnosis of HD has not been previously evaluated. We studied 36 patients, with equal distribution of men and women, mean age 53.9 (SD 12.3) years (range 25-76) and mean duration of symptoms of $11 \cdot 2$ (SD 7.7) years (range 2-33), whose clinical diagnosis of HD was confirmed by expanded CAG repeats $(>40)$. Coping strategies and depression levels were assessed before the results of DNA testing were imparted. The assessments were repeated two weeks and three months after the results were explained to the patients and their relatives and were compared to the baseline assessments. This group of HD patients was compared with 10 patients who had similar symptoms but the diagnosis of $\mathrm{HD}$ was excluded by normal CAG repeats $(<30)$. Although some patients with HD expressed a subjective reaction to the positive result (four were "surprised", one was "frustrated", and one "devastated"), there were no differences in any psychological scores including Beck Depression Inventory, functional capacity, symptom interference, independence scale, and other measures of mood and behaviour two weeks and three months later. Similarly, no change was noted in any of these measures in the nonHD group. These results suggest that mood and coping strategies are unaffected by DNA confirmation of diagnosis in symptomatic patients with HD.
\end{abstract}

Department of Neurology,

Parkinson's Disease Center and Movement Disorders Clinic, Baylor College of Medicine, 6550 Fannin No 1801, Houston, Texas 77030, USA J Jankovic J Beach

T Ashizawa

Correspondence to: Professor Jankovic.

Received 15 November 199 Revised version accepted for publication

20 February 1995

\section{(f Med Genet 1995;32:516-518)}

Huntington's disease (HD) is an incurable her10000 to 25000 people in the United States. ${ }^{1}$ With the increasing availability of DNA diagnostic testing, questions about coping strategies in response to diagnosis of a terminal illness are being addressed by a growing number of investigators. $^{2-5}$ While the potential impact of DNA testing on asymptomatic subjects at risk for HD has been addressed by numerous reports, ${ }^{6-12}$ the effect of communicating the genetic results to patients with a previous clinical editary neurological disorder affecting about diagnosis of HD has not been evaluated before. This study was designed to address the question of whether genetic confirmation of a clinical diagnosis of HD will have an adverse impact on mood and coping strategies in these patients.

\section{Methods}

Thirty six patients with the clinical diagnosis of HD participated in this study after signing a consent form approved by the Institutional Review Board for Human Research at Baylor College of Medicine. The patients in the HD group had already been told that they most probably had HD, based on typical clinical presentation and family history of $\mathrm{HD}$ (present in at least one first degree relative of 30 of the 36 patients). This group of patients with HD was compared with a group of 10 patients in whom HD was initially suspected, but it was excluded by genetic testing. In this latter group there were three patients with neuroacanthocytosis, two with idiopathic chorea, and one each with Sydenham's chorea, hereditary ataxia, chorea associated with exposure to vinyl chloride, tardive dyskinesia, and HallervordenSpatz disease. Three of 10 patients in this nonHD group had a family history of a movement disorder among their first degree relatives. The diagnosis of HD was confirmed if the blood DNA analysis, performed by a previously described method ${ }^{6}$ using primers that exclude the adjacent polymorphic CCG repeats, indicated $>40 \mathrm{CAG}$ repeats, and it was excluded if the number of CAG repeats was $<30$.

The subjects were asked to complete questionnaires designed to measure mood and to assess patient's functional capacity. Depression was measured with the Beck Depression Inventory, ${ }^{13}$ functional capacity was assessed with staging of functional capacities, ${ }^{14}$ degree of functional impairment was rated on modified Physical Disability/Independence Rating Scale, ${ }^{15}$ and modified Behavioral and Functional Assessment measures from the Unified Huntington's Disease Rating Scale were used to evaluate mood, self-esteem, guilt, anxiety, suicidal thoughts, aggressive behaviour, and functional capacity. ${ }^{15}$

Statistical analysis was performed using the Wilcoxon rank sum test to compare non-parametric measures in the positive versus negative group. The non-parametric signed rank test for paired comparisons was used to analyse changes in each group from baseline to first 
Table 1 Assessment of impact of communicating the results of DNA testing on patients with known Huntington's disease

\begin{tabular}{llll}
\hline Variable & Baseline & Follow up at 2 weeks & Follow up at 3 months \\
\hline Number & 36 & 31 & 28 \\
Age (mean (SD)) & $53 \cdot 9(12 \cdot 3)$ & $53 \cdot 1(13 \cdot 8)$ & $53 \cdot 6(11 \cdot 7)$ \\
Duration of symptoms (y) & $(25-76)$ & $(25-76)$ & $(25-76)$ \\
& $11 \cdot 2(7 \cdot 7)$ & $11 \cdot 2(7 \cdot 8)$ & $11 \cdot 5(7 \cdot 9)$ \\
Female/male & $(2-33)$ & $(2-33)$ & $(2-33)$ \\
Beck Depression Scale & $18 / 18$ & $14 / 17$ & $14 / 14$ \\
& $14 \cdot 6(9 \cdot 9)$ & $14 \cdot 5(9 \cdot 1)$ & $14 \cdot 1(10 \cdot 8)$ \\
Functional capacity & $(0-41)$ & $(1-35)$ & $(0-41)$ \\
Functional assessment & $6 \cdot 4(3 \cdot 5)$ & $6 \cdot 3(3 \cdot 5)$ & $6 \cdot 4(3 \cdot 4)$ \\
Symptom interference & $(0-13)$ & $(0-13)$ & $(1-13)$ \\
& $605(62 \%)$ & $505(60 \%) \mathrm{Y}$ & $452(60 \%) \mathrm{Y}$ \\
Independence scale & $(0-8)$ & $4 \cdot 3(2 \cdot 2)$ & $4 \cdot 3(2 \cdot 4)$ \\
& $70 \cdot 4(25 \cdot 6)$ & $(0-8)$ & $(0-8)$ \\
Sad mood & $(10-100)$ & $(10-100)$ & $73 \cdot 4(22 \cdot 6)$ \\
& $1 \cdot 2(1 \cdot 2)$ & $1 \cdot 3(1 \cdot 3)$ & $(10-100)$ \\
Low self-esteem/guilt & $(0-4)$ & $(0-4)$ & $1 \cdot 5(1 \cdot 5)$ \\
& $1 \cdot 1(1 \cdot 3)$ & $0 \cdot 8(1 \cdot 1)$ & $(0-4)$ \\
Anxiety & $(0-4)$ & $(0-3)$ & $1 \cdot 0(1 \cdot 3)$ \\
Suicidal ideation & $1 \cdot 3(1 \cdot 4)$ & $1 \cdot 1(1 \cdot 2)$ & $(0-4)$ \\
& $(0-4)$ & $(0-4)$ & $1 \cdot 3(1 \cdot 2)$ \\
Aggressive behaviour & $0 \cdot 3(0 \cdot 7)$ & $0 \cdot 3(0 \cdot 5)$ & $(0-4)$ \\
& $(0-3)$ & $(0-2)$ & $0 \cdot 3(0 \cdot 7)$ \\
& $0 \cdot 6(0 \cdot 9)$ & $0 \cdot 3(0 \cdot 6)$ & $(0-3)$ \\
& $(0-3)$ & $(0-3)$ & $0 \cdot 4(0 \cdot 8)$ \\
\end{tabular}

Table 2 Assessment of impact of communicating the results of negative DNA tests on patients with suspected Huntington's disease

\begin{tabular}{|c|c|c|c|}
\hline Variable & Baseline & Follow up at 2 weeks & Follow up at 3 months \\
\hline $\begin{array}{l}\text { Number } \\
\text { Age (mean (SD)) }\end{array}$ & $\begin{array}{l}10 \\
45 \cdot 6(18 \cdot 9) \\
(13-68)\end{array}$ & $\begin{array}{l}8 \\
46 \cdot 1(19 \cdot 3) \\
(13-68)\end{array}$ & $\begin{array}{l}6 \\
50 \cdot 8(19 \cdot 9) \\
(13-68)\end{array}$ \\
\hline Duration of symptoms (y) & $\begin{array}{l}13 \cdot 9(10 \cdot 5) \\
(1-38)\end{array}$ & $\begin{array}{l}14 \cdot 7(11 \cdot 2) \\
(1-38)\end{array}$ & $\begin{array}{l}16 \cdot 0(11 \cdot 4) \\
(8-38)\end{array}$ \\
\hline $\begin{array}{l}\text { Female/male } \\
\text { Beck Depression Scale }\end{array}$ & $\begin{array}{l}4 / 6 \\
7 \cdot 1(4 \cdot 8) \\
(0-14)\end{array}$ & $\begin{array}{l}3 / 5 \\
6 \cdot 6(4 \cdot 1) \\
(0-15)\end{array}$ & $\begin{array}{l}3 / 3 \\
7 \cdot 3(5 \cdot 1) \\
(0-15)\end{array}$ \\
\hline Functional capacity & $\begin{array}{l}6 \cdot 8(4 \cdot 1) \\
(2-13)\end{array}$ & $\begin{array}{l}6 \cdot 9(2 \cdot 4) \\
(4-12)\end{array}$ & $\begin{array}{l}6 \cdot 8(4 \cdot 1) \\
(2-13)\end{array}$ \\
\hline $\begin{array}{l}\text { Functional assessment } \\
\text { Symptom interference }\end{array}$ & $\begin{array}{l}139(51 \%) \mathrm{Y} \\
4.5(2 \cdot 3) \\
(0-8)\end{array}$ & $\begin{array}{l}129(60 \%) \mathrm{Y} \\
3 \cdot 3(2 \cdot 2) \\
(0-6)\end{array}$ & $\begin{array}{c}91(56 \%) Y \\
3 \cdot 3(2 \cdot 3) \\
(0-7)\end{array}$ \\
\hline Independence scale & $\begin{array}{l}69 \cdot 0(16 \cdot 4) \\
(50-100)\end{array}$ & $\begin{array}{l}73 \cdot 7(16 \cdot 5) \\
(50-100)\end{array}$ & $\begin{array}{l}75 \cdot 0(17 \cdot 1) \\
(50-100)\end{array}$ \\
\hline Sad mood & $\begin{array}{l}0 \cdot 9(0 \cdot 9) \\
(0-3)\end{array}$ & $\begin{array}{l}1 \cdot 5(1 \cdot 3) \\
(0-3)\end{array}$ & $\begin{array}{l}1 \cdot 0(1 \cdot 1) \\
(0-3)\end{array}$ \\
\hline Low self-esteem/guilt & $\begin{array}{l}0 \cdot 4(0 \cdot 5) \\
(0-1)\end{array}$ & $\begin{array}{l}0 \cdot 4(0 \cdot 7) \\
(0-2)\end{array}$ & $\begin{array}{l}0 \cdot 5(1 \cdot 1) \\
(0-3)\end{array}$ \\
\hline Anxiety & $\begin{array}{l}1 \cdot 4(1 \cdot 0) \\
(0-3)\end{array}$ & $\begin{array}{c}1 \cdot 0(1 \cdot 1) \\
(0-3)\end{array}$ & $\begin{array}{c}1 \cdot 2(1 \cdot 2) \\
(0-3)\end{array}$ \\
\hline Suicidal ideation & 0 & $\begin{array}{l}0 \cdot 4(1 \cdot 0) \\
(0-3)\end{array}$ & 0 \\
\hline Aggressive behaviour & $\begin{array}{l}0 \cdot 2(0 \cdot 4) \\
(0-1)\end{array}$ & $\begin{array}{l}0.2(0 \cdot 4) \\
(0-1)\end{array}$ & $\begin{array}{l}0 \cdot 2(0 \cdot 4) \\
(0-1)\end{array}$ \\
\hline
\end{tabular}

follow up evaluation and from baseline to second follow up evaluation.

\section{Results}

All (100\%) subjects, "positive" and "negative", responded to the baseline questionnaire. In the "positive" group, 31/36 (86\%) responded at two weeks and $28 / 36(78 \%)$ responded at three months. In the "negative" group $8 / 10(80 \%)$ responded at two weeks and $6 / 10(60 \%)$ responded at three months. Although 29 of 34 patients with clinically diagnosed HD expressed no surprise when the positive DNA results were first communicated to them, four were "surprised", one was "frustrated", and one was "devastated". There was no change in any psychological score including the Beck Depression Inventory, functional capacity, symptom interference, independence scale, and other measures of mood and behaviour two weeks and three months later in the HD group (table 1). Similarly, there was no difference in the respective scores in the non-HD group (table 2).

\section{Discussion}

Most studies of the effects of DNA testing on the psychological and functional measures have concentrated on asymptomatic people who carry $25 \%$ or $50 \%$ risk of inheriting the HD gene. The vast majority of DNA testing, however, involves subjects who are clinically affected and in whom the DNA test provides a definitive confirmation of the diagnosis. Some of these subjects have been previously diagnosed as having $\mathrm{HD}$ based on clinical presentation, while others seek the test because they believe that they are asymptomatic although the neurological examination indicates evidence of $\mathrm{HD}$. As many as $15 \%$ of those requesting predictive testing for $\mathrm{HD}$ have clinical evidence of the disease at the time of the initial examination. ${ }^{816}$ DNA testing is also used to exclude the diagnosis of $\mathrm{HD}$ in patients whose clinical course resembles that of HD.

Our study shows that communicating a positive result of DNA testing in patients with a clinical diagnosis of HD has not resulted in any detectable change in mood, behaviour, coping strategies, or functional capacity. Similarly, in another group of patients in whom HD was suspected, but, because of lack of family history or atypical findings, the diagnosis was in doubt, there was no change in any of the measured variables after DNA testing for $\mathrm{HD}$ was found to be negative.

Although no similar study has been previously performed, the results are not entirely surprising. Psychological and other outcome studies in asymptomatic, at risk subjects have indicated relatively minimal impact of either positive or negative DNA test results. In one study, four of 15 DNA tests on presymptomatic subjects using linkage analysis were positive for the HD gene. ${ }^{17}$ While all those with positive results experienced transient symptoms of depression, none reported suicidal ideation. Another study showed that one year after the results of gene testing were disclosed, both increased risk and decreased risk subjects had overall no increase in depression or deterioration in psychological well being. ${ }^{7}$ Despite these findings, the potential risk of catastrophic psychological reaction to positive, and even negative, test results strongly argues in favour of intensive pre- and post-test genetic and psychological counselling in all asymptomatic persons. ${ }^{89}$

Our results suggest that since mood and coping strategies are unaffected by DNA confirmation of the diagnosis in symptomatic patients with $\mathrm{HD}$, extensive psychological testing and counselling do not seem necessary in most such patients. Given the state of denial, however, in some symptomatic patients with clinically diagnosed $\mathrm{HD}$, it is prudent to exercise caution when imparting the results of DNA HD tests in these patients. Although our patients showed no deterioration in mood, none showed evidence of serious depression at the time when the DNA results were communicated. In patients who show evidence of depression, the positive DNA test results may precipitate more profound depression and, therefore, the diagnosis may need to be delayed 
until the patient is determined to be "ready". Although appropriate counselling and psychological support should be made available to the patients, rather than insisting on uniform guidelines, we recommend that the approach to DNA test results should be individualised and handled lucidly and compassionately.

We thank Dr Myrna Khan for performing the statistical analyses of the data. The DNA diagnoses were provided by Dr Sue Richards and Lee-Jun Wong of the Kleberg DNA Diagnostic Laboratory at Baylor College of Medicine.

1 Kokmen E, Özekmekci S, Beard CM, et al. Incidence and prevalence of Huntington's disease in Olmsted county, prevalence of Huntington's disease in Olmsted county,
Minnesota (1950 through 1989). Arch Neurol 1994;51: 696-8.

2 Jankovic J, Ashizawa T. Huntington's disease. In: Appel, SH, ed. Current neurology. Vol 15. Chicago: Mosby Year Book, 1995.

3 Gusella JF, Wexler NS, Conneally PM, et al. A polymorphic DNA marker genetically linked to Huntington's disease. Nature 1983;306:234-8.

4 The Huntington's Disease Collaborative Research Group. A novel gene containing a trinucleotide repeat that is expanded and unstable on Huntington's disease chromosomes. Cell 1993;72:971-83.

5 Kremer B, Goldberg P, Andrew SE, et al. A worldwide study of Huntington's disease mutation: the sensitivity
and specificity of measuring CAG repeats. $N$ Engl $f$ Med 1994;330:1401-6.
6 Ashizawa T, Wong LJC, Richards CS, et al. CAG repeat size and clinical presentation in Huntington's disease. size and clinical presentation

7 Wiggins S, Whyte P, Huggins $M$, et al. The psychological iggins $\mathrm{S}$, Whyte $\mathrm{P}$, Huggins $\mathrm{M}$, et al. The psychological
consequences of predictive testing for Huntington's disconsequences of predictive testing for
ease. $N$ Engl f Med 1992;327:1401-5.

8 Bloch M, Adam S, Fuller A, et al. Diagnosis of Huntington's disease: a model for the stages of psychological response based on experience of a predictive testing program. $A m$ $\mathcal{f}$ Med Genet 1993;47:368-74.

9 Motulsky AG. Invited editorial. Predictive genetic diagnosis. Am $\mathcal{F}$ Hum Genet 1994;55:603-5.

10 Hersch S, Jones R, Koroshetz W, Quaid K. The neurogenetics genie: testing for the Huntington's disease mutation. Neurology 1994;44:1369-73.

11 International Huntington Association and World Federation of Neurology Research Group on Huntington's Chorea. Guidelines for the molecular genetics predictive test in Huntington's disease. Neurology 1994;44:1533-6.

12 Benjamin CM, Adam S, Wiggins S, et al. Proceed with care: direct predictive testing for Huntington's disease. $A m \mathcal{F}$ direct predictive testing for

13 Beck AT, Ward CH, Mendelson M, et al. An inventory for measuring depression. Arch Gen Psychiatry 1961;4: for measuri

14 Shoulson I. Huntington's disease: functional capacities in patients treated with neuroleptic and antidepressant drugs. Neurology 1981;31:1333-5.

15 The Huntington Study Group. Unified Huntington disease rating scale. Mot Disord (in press).

16 Brandt J, Quaid KA, Folstein SE, et al. Presymptomatic diagnosis of delayed-onset disease with linked DNA markers. $尹 A M A$ 1989;261:3108-14.

17 Meissen GJ, Myers RH, Mastromauro CA, et al. Predictive testing for Huntington's disease with use of linked DNA marker. $N$ Engl f Med 1988;318:535-42. 